\title{
Potential of Normalized Difference Vegetation Index for Mapping of Soft Clay Area in Paddy Fields of Kedah, Malaysia
}

\author{
Muhammad Rendana'), Wan Mohd Razi Idris ${ }^{2 *}$, Sahibin Abdul Rahim ${ }^{3)}$, Zulfahmi Ali Rahman ${ }^{2)}$ and \\ Tukimat Lihan ${ }^{2)}$ \\ Chemical Engineering Program, Faculty of Engineering, Universitas Sriwijaya, Indralaya 30662 Sumatera \\ Selatan, Indonesia. ${ }^{2}$ Environmental Sciences Program, Faculty of Science and Technology, Universiti \\ Kebangsaan Malaysia, 43600 Bangi, Selangor, Malaysia. ${ }^{3}$ Environmental Science Program, Faculty of \\ Science and Natural Resources, Universiti Malaysia Sabah, 88400 Kota Kinabalu, Sabah, Malaysia.
}

Received: 2019-02-16

Accepted: 2019-12-09

Key words:

Normalized Difference

Vegetation Index;

Paddy planting;

Remote sensing;

Soft clay.

Correspondent email: razi@ukm.edu.my

\begin{abstract}
Mapping of soft clay area in paddy fields uses remote sensing and GIS technique is the fastest way to obtain an accurate location of soft clay in a large scale area. It can be an alternative way to change conventional method like in-situ observation that is expensive and labor intensive. Therefore, this study aimed to investigate the normalized difference vegetation index (NDVI) to map soft clay area in paddy fields Kedah, Malaysia. To analyze soft clay area comprehensively, the study was carried out in three different periods; before paddy planting, after paddy planting and harvest. Ground-truth data of soft clay area was collected from study area during fieldwork activity and compared with NDVI values that produced from Landsat 8 image. Result of study showed NDVI map in period of before paddy planting could be a good indicator for mapping soft clay area because it gave a higher accuracy value than the other periods, with overall accuracy $(85 \%)$ and kappa coefficient $(0,84)$. Total area of soft clay from the highest value was showed in period of before paddy planting $(1.856,97 \mathrm{ha})$, followed by after paddy planting $(656,73 \mathrm{ha})$ and harvest $(401,85 \mathrm{ha})$ periods, respectively.
\end{abstract}

2020 by the authors. Licensee Indonesian Journal of Geography, Indonesia.
This article is an open access article distributed under the terms and conditions of the Creative Commons

the article an open access

\section{Introduction}

Soft clay is infertile soil that characterized with low strength of soil. It affects rice production because agricultural machines cannot be operated at the soil. In Kedah, Malaysia, 8,107 ha of total paddy fields has experienced a great deal of soft clay problem (New Straits Time, 2013). With no proper soil improvement carried out at this area, slowing down in yield will increase. In natural condition, soft clay is distinguished with bare area and sometimes patches of water around paddy fields (Rendana et al., 2019a; Rendana et al., $2019 b$ ). They are some unique features that identified as the link with soft clay occurrence. But, to obtain an accurate ground-based observation of soft clay in a large scale area is difficult, labor intensive, expensive and time consuming. These challenges have led many researchers studied the remote sensing (RS) and geographical information system (GIS) technique because both offered a quick way in classifying land cover features (Rendana et al., 2016; Shafian \& Maas, 2015).

The Landsat 8 satellite captures land cover image in a specific area that affected by soil and vegetation characteris- tic. This is a basic of using remote sensing technique in assessing the land cover in various studies. Results of many studies have reported a great capacity of spectral band that derived from vegetation index for assessing soil and vegetation (Rendana et al., 2017). Over the years, the vegetation index has been applied in land cover evaluation in response on spatial and temporal variations (Mallick et al., 2009; Holzman et al., 2014).

To date, limited works have been done previously on the Landsat 8-based normalized difference vegetation index (NDVI) in mapping soft clay area. To distinguish the soft clay area in paddy fields using the NDVI index, firstly, we need some indicators from study area such as bare area and patches of water around the paddy fields. In addition, the soft clay soil has higher soil moisture content than normal soil. Many studies have successfully applied some vegetation indices from multispectral satellite in detecting soil moisture content. Multispectral indices like the soil adjusted vegetation index (SAVI), enhanced vegetation index (EVI) and vegetation condition index (VCI) have been widely used to 
evaluate soil moisture and drought event (Huete et al., 2002). Specifically, the normalized difference vegetation index (NDVI) has been central to regional scale of soil moisture detection. The NDVI becomes a key parameter of the indices listed above and commonly applied in analyzing soil moisture content because it is capable to assess available moisture or water content in plant cell and soil (Wang et al., 2007; Chen et al., 2014; Ahmed et al., 2017). As a whole, it can be a suitable parameter for the study. Therefore, the study aimed to investigate potential of normalized difference vegetation index (NDVI) in mapping of soft clay area in the paddy fields. Findings from the study were expected to give further understanding of remote sensing and GIS technique in evaluating spatial variation of the soft clay area.

\section{The Methods}

Study area was located in MADA paddy cultivation area (Region-III) Kedah, Malaysia (Figure 1). It was divided by three regions; B-III Region $\left(6^{\circ} 6^{\prime} 00.00^{\prime \prime N}, 100^{\circ} 27^{\prime} 00.00^{\prime E}\right)$, CIII Region $\left(6^{\circ} 3^{\prime} 00.00^{\prime \prime} \mathrm{N}, 100^{\circ} 24^{\prime} 00.00^{\prime \prime E}\right)$ and D-III Region $\left(6^{\circ} 3^{\prime} 00.00^{\prime \prime} \mathrm{N}, 100^{\circ} 30^{\prime} 00.00^{\prime \prime E}\right)$. Total area of study was about $16.284,60$ ha. The area has experienced low rice yield because of soft clay problem (Nadzim et al., 2014). Soft clay was characterized with high compressibility and low strength (Azizul, 2008; Rendana et al., 2018). The low soil strength value lead to decline ground pressure capability of agricultural machine.
Landsat 8 operational land imager (OLI) satellite image was downloaded from USGS Earth Explorer website. Landsat 8 OLI \& thermal infrared sensor (TIRS) had nine spectral bands with spatial resolution of $30 \mathrm{~m}$ for band 1 to 7 and 9 , $15 \mathrm{~m}$ for panchromatic band 8 and $100 \mathrm{~m}$ for thermal band 10 and 11. In this study, mapping of soft clay area was carried out in three periods of paddy planting such as before paddy planting, after paddy planting and harvest. It was done to obtain the best result for mapping of soft clay area.

Atmospheric correction was a process for minimizing negative effects on satellite image before it could be used for land cover analysis such as fog, dust, tiny particle and the other disturbances on the atmosphere. It consisted of two main processes; (i) top of Atmosphere (TOA) reflectance and (ii) TOA reflectance with the sun angle correction. Top of Atmosphere (TOA) reflectance was a conversion of digital number (DN) from radiance to reflectance value. The atmospheric correction was calculated using formula from USGS (U.S. Geological Survey) in equation 1.

$\mathrm{R}_{\mathrm{l}^{\prime}}=\mathrm{M}_{\mathrm{l}} \mathrm{Q}_{\mathrm{cal}}+\mathrm{A}_{\mathrm{r}}$

$\mathrm{R}_{\mathrm{l}}=$ TOA reflectance without sun angle correction,

$\mathrm{M}_{1}=$ parameter "REFLECTANCE_MULT_BAND_x" in metadata file.

$\mathrm{Q}_{\mathrm{cal}}=$ standardized pixel number.

$\mathrm{A}_{\mathrm{r}}=$ parameter "REFLECTANCE_MULT_BAND_x" in metadata file.

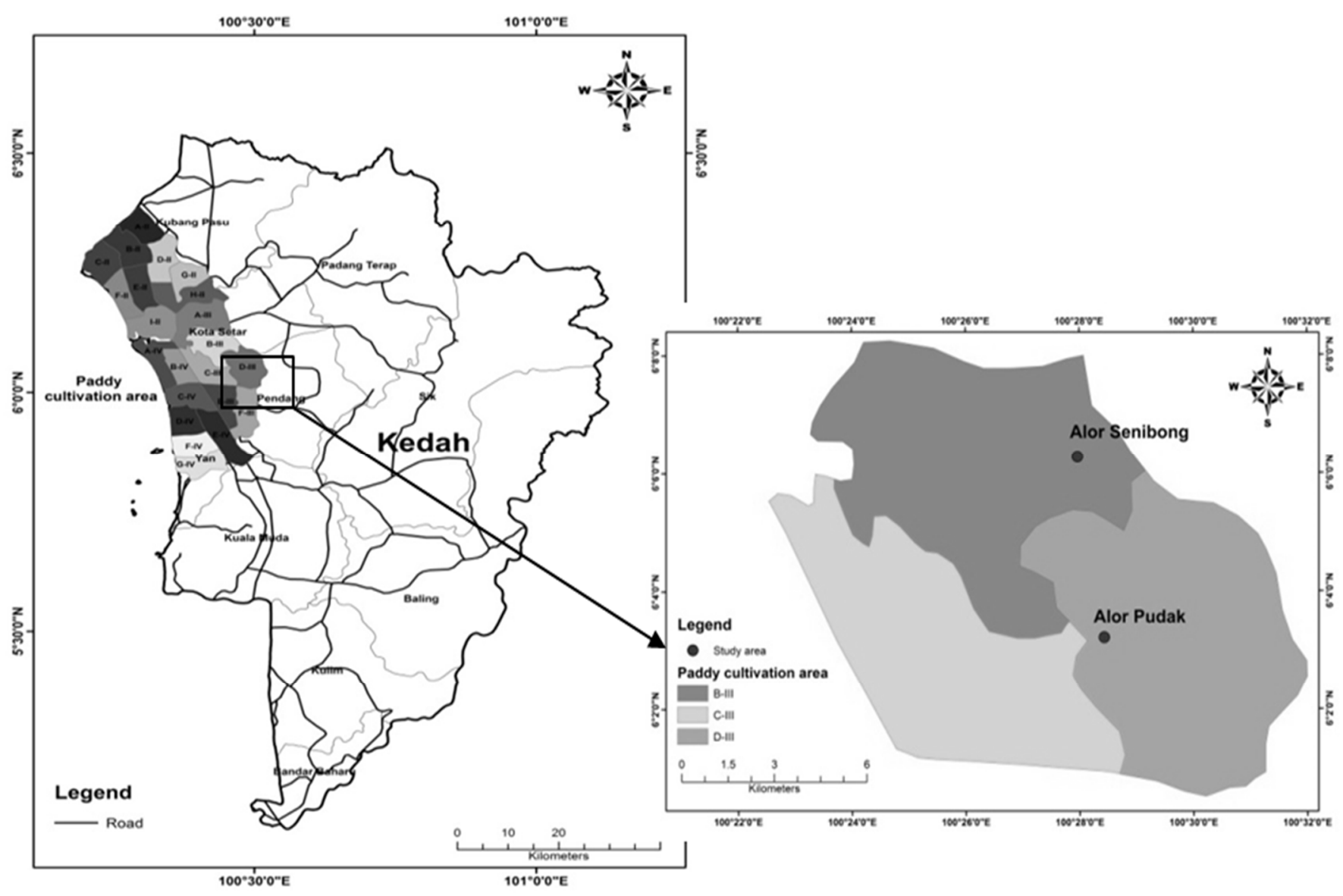

Figure 1. Location of study area. 
$\mathrm{R}_{1}=\mathrm{R}_{\mathrm{l}^{\prime}} / \cos \left(\right.$ sun zenith angle) or $\mathrm{R}_{\mathrm{l}}=\mathrm{R}_{\mathrm{l}^{\prime}} / \sin ($ sun elevation angle)

$\mathrm{R}_{1}=$ TOA reflectance, $\mathrm{R}_{\mathrm{l}^{\prime}}=$ TOA reflectance without

correction.

Sun elevation angle $=$ parameter "SUN_ELEVATION" in metadata file.

Sun zenith angle $=90$ - Sun elevation angle.

Landsat 8 images were downloaded in three periods of paddy planting; before paddy planting, after paddy planting and harvest period. In many studies, the normalized difference vegetation index (NDVI) has been used to study canopy growth and fertility of plant (Gopalapillai \& Tian, 1999). Near-infrared band was a sensitive in changing of chlorophyll content thus it could be used to determine land cover features in a certain area. The NDVI capability for assessing land cover features was a very useful method for mapping of soft clay area. Because of the soft clay had unique characteristics such as bare area and patches of water at soil surface (Figure 2). For this reason, the NDVI could be used to detect available moisture or water content in the soil. Therefore, the NDVI became a good parameter selected in the study. In general, the NDVI was calculated using the near-infrared band 5 and red band 4 from spectral band of the Landsat 8 image as shown in equation 2. NDVI values normally ranged from -1 to 1 . For dense canopy or vegetation area, it showed the NDVI value near 1, while for bare area or water body showed the NDVI value near -1. It was classified in accordance classification from Rouse et al. (1974). Overall of GIS analysis was conducted using ArcGIS software Ver. 10.

$$
\begin{aligned}
& \text { NDVI }=(\text { NIR }(\text { band } 5)-\text { Red }(\text { band } 4)) /(\text { NIR }(\text { band } 5)+ \\
& \text { Red }(\text { band } 4))
\end{aligned}
$$

Sampling activity was conducted to obtain ground-truth data of soft clay location in study area. Total of 31 sampling points has been successfully recorded using DGPS Trimble Geo XM (Figure 3). It was used to validate NDVI maps from

$$
K=\frac{N \sum_{i=1}^{r} x_{i i}-\sum_{i=1}^{r}\left(x_{i}+X x_{+1}\right)}{N^{2}-\sum_{i=1}^{r}\left(x_{i i} X x_{+1}\right)}
$$

GIS analysis. Accuracy assessment was calculated using kappa statistic. The kappa statistic formula has been shown in equation 3 that referred from Jensen (1996). Kappa coefficient was equal to 1 implied a perfect agreement while for the value closed to zero implied the agreement was no better than it would be expected by chance.

$r=$ number of rows and columns in error matrix.

$N=$ total number of observations (pixels).

$X i i=$ observation in row $i$ and column $i$.

$X i+=$ marginal total of row $i$.

$X+i=$ marginal total of column $\mathrm{i}$.

\section{Results and Discussion}

\section{Normalized difference vegetation index (NDVI) classification}

In this study, classification of NDVI value was adopted from Jwan et al. (2013). Sparse vegetation ranged from 0,2 to 0,4 , moderate vegetation ranged from 0,4 to 0,6 and dense vegetation ranged from 0,6 to 0,9 . While, for the NDVI value was less than 0,2 , it indicated water body or area without vegetation cover. Based on result of study and ground-truth data, the study believed the NDVI value $(<0,2)$ indicated the soft clay area. Nadzim et al. (2014) stated the soft clay had soil strength was less than 0,40 MPa thus it inhibited paddy growth. The soft clay area was exhibited by blue color at NDVI maps (Figure 4). Bambang and Ahmad (2014) explained both water body and bare area had a lower NDVI value than vegetation area because of chlorophyll content. The chlorophyll absorbed more sun light in visible spectrum, especially in red spectrum. Total of the soft clay area obtained through GIS analysis in period of harvest (401,85 ha) was a slightly lower than period of after paddy planting (656,73 ha) and before paddy planting (1.856,97 ha) (Table
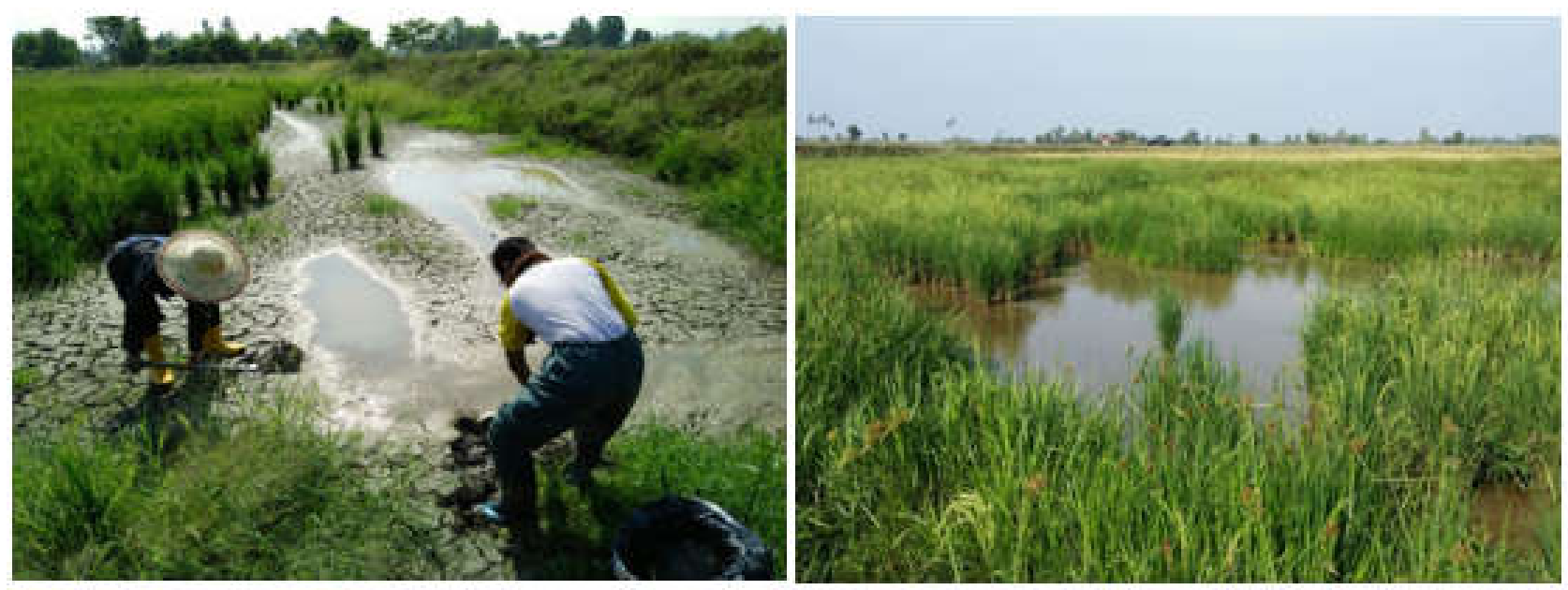

Figure 2. Pictures of soft clay in study area. 
1). Many soft clay areas were covered by irrigation water in period of after paddy planting that resulted in decreasing of them. Contrarily, in period of harvest and before planting, paddy fields were in drying condition that attributed in increasing total of reflectance of soft clay area.

There was a significant change at dense vegetation class (NDVI 0,6-0,9) in period of after paddy planting. It showed increasing total area of the class $(8,881.65 \mathrm{ha})$. It might occur because paddy plants have grown with high density thus it raised NDVI value. This notion was consistent with a finding of Ajith et al. (2017) who found the NDVI value in paddy fields during growing season was around 0,81. For harvest period, sparse vegetation class (NDVI 0,2-0,4) was a predominant in study area. It dominated approximately of $48 \%$ from total area of study. Mosleh and Hassan (2014) found the NDVI value of paddy fields in Bangladeshi during harvest season was around 0,45 . The value was a slightly higher than current study. When it was compared with previous studies, this finding might be affected by several aspects such as location of area and species of paddy. The variation of paddy species could reflect distinct chlorophyll and NDVI values.

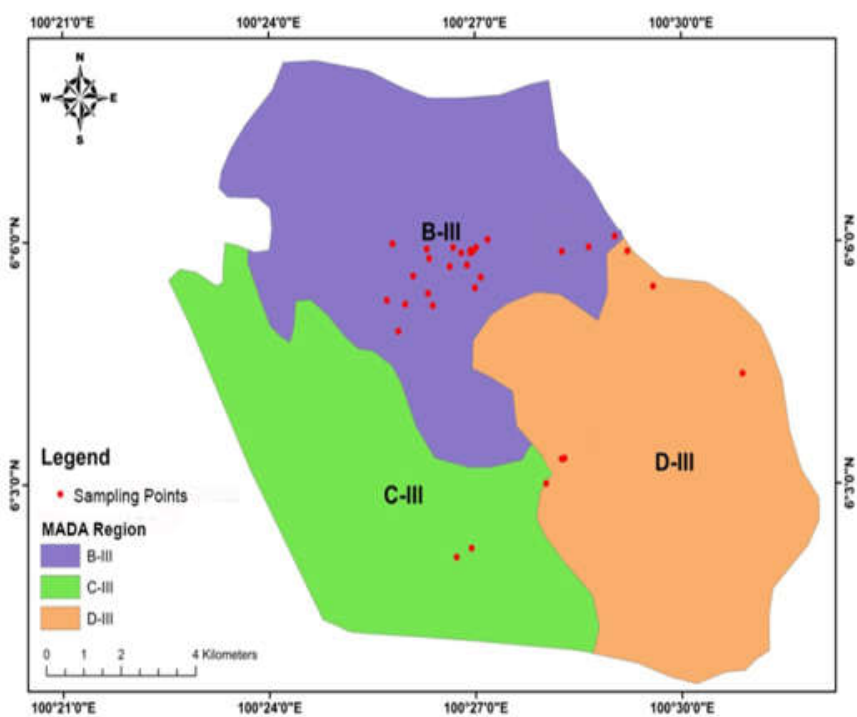

Figure 3. Distribution of sampling point in study area.

Table 1. Total area of NDVI classes in three periods of paddy planting.

\begin{tabular}{llll}
\hline & \multicolumn{3}{c}{ Period of Paddy Planting } \\
\cline { 2 - 4 } & $\begin{array}{l}\text { Before } \\
\text { Planting } \\
\text { (ha) }\end{array}$ & $\begin{array}{l}\text { After } \\
\text { Planting } \\
\text { (ha) }\end{array}$ & $\begin{array}{l}\text { Harvest } \\
\text { (ha) }\end{array}$ \\
\hline $\begin{array}{l}\text { NDVI Classes } \\
\text { Area(<0,2) }\end{array}$ & $1,856.97$ & 656,73 & 401,85 \\
$\begin{array}{l}\text { Sparse Vegetation } \\
(0,2-0,4)\end{array}$ & $10,480.23$ & $2,487.24$ & $7,870.23$ \\
$\begin{array}{l}\text { Moderate Vegetation } \\
(0,4-0.6)\end{array}$ & $2,512.26$ & $4,258.98$ & $4,523.58$ \\
$\begin{array}{l}\text { Dense Vegetation } \\
(0,6-0,9)\end{array}$ & $1,435.14$ & $8,881.65$ & $3,488.94$ \\
\hline
\end{tabular}

Accuracy assessment

Accuracy assessment was carried out using confusion matrix on NDVI map (Table 3-5). In this study, the highest value of overall accuracy and kappa coefficient was showed in the period of before paddy planting with values of $85 \%$

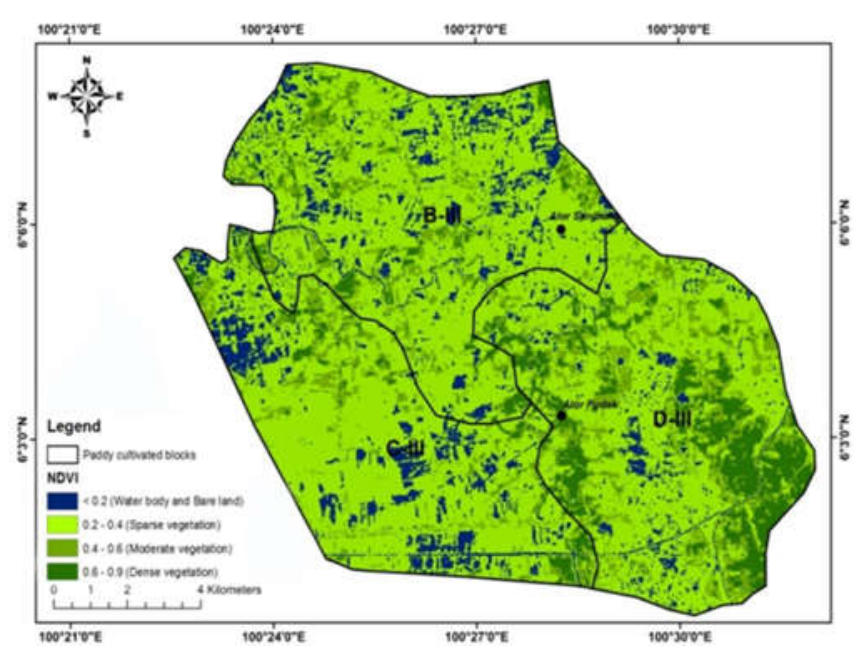

(a)

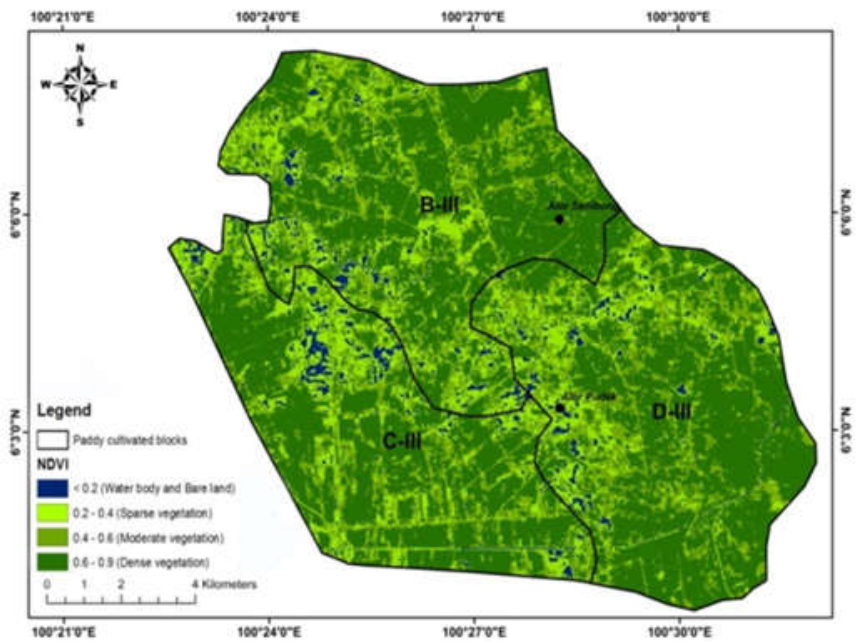

(b)

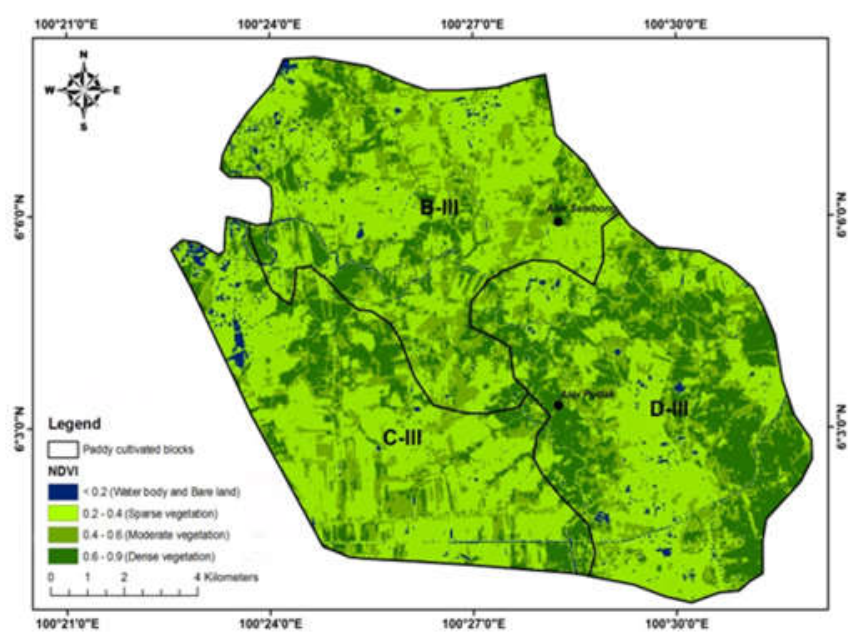

(c)

Figure 4. NDVI maps in study area (a) period of before paddy planting, (b) period of after paddy planting and (c) period of harvest. 
Table 2. Accuracy assessment of NDVI classes based on statistical parameters.

\begin{tabular}{|c|c|c|c|c|c|c|c|c|c|c|c|c|}
\hline \multirow{4}{*}{ NDVI Classes } & \multicolumn{12}{|c|}{ Periods } \\
\hline & \multirow{2}{*}{\multicolumn{4}{|c|}{$\frac{\text { Before Paddy Planting }}{\text { Parameters }}$}} & \multirow{2}{*}{\multicolumn{4}{|c|}{$\begin{array}{c}\text { After Paddy Planting } \\
\text { Parameters }\end{array}$}} & \multirow{2}{*}{\multicolumn{4}{|c|}{$\begin{array}{c}\text { Harvest Period } \\
\text { Parameters }\end{array}$}} \\
\hline & & & & & & & & & & & & \\
\hline & $\mathrm{OE}$ & $\mathrm{CE}$ & UA & PA & $\mathrm{OE}$ & $\mathrm{CE}$ & UA & PA & $\mathrm{OE}$ & $\mathrm{CE}$ & UA & PA \\
\hline $\begin{array}{l}\text { Water Body or Bare } \\
\text { Area }\end{array}$ & 0,15 & 0,104 & 0,85 & 0,85 & 1 & 0 & 0 & 0 & 0,70 & 0 & 1 & 0,30 \\
\hline Sparse Vegetation & 0,15 & 0,111 & 0,71 & 0,85 & 0,95 & 0,24 & 0,05 & 0,05 & 0,45 & 0,188 & 0,46 & 0,55 \\
\hline Moderate Vegetation & 0,15 & 0,016 & 0,94 & 0,85 & 0,70 & 0,121 & 0,40 & 0,30 & 0,70 & 0,135 & 0,38 & 0,30 \\
\hline Dense Vegetation & 0,15 & 0,016 & 0,94 & 0,85 & 0,75 & 0,36 & 0,16 & 0,25 & 0,10 & 0,258 & 0,53 & 0,90 \\
\hline
\end{tabular}

${ }^{\star} \mathrm{OE}$ : Omission Error; CE: Commission Error; PA: Producer's Accuracy; UA: User's Accuracy.

Table 3. The matrix table of NDVI classification before paddy planting period.

\begin{tabular}{|c|c|c|c|c|c|c|}
\hline \multirow[b]{2}{*}{ NDVI Classes } & \multicolumn{4}{|c|}{ Reference Value } & \multirow[b]{2}{*}{ Total } & \multirow[b]{2}{*}{$\begin{array}{l}\text { Correct } \\
\text { Sampled }\end{array}$} \\
\hline & $\begin{array}{l}\text { Water Body } \\
\text { or Bare Area }\end{array}$ & $\begin{array}{l}\text { Sparse Vegeta- } \\
\text { tion }\end{array}$ & $\begin{array}{l}\text { Moderate } \\
\text { Vegetation }\end{array}$ & $\begin{array}{l}\text { Dense Vegeta- } \\
\text { tion }\end{array}$ & & \\
\hline Water Body or Bare Area & 17 & 3 & 0 & 0 & 20 & 17 \\
\hline Sparse Vegetation & 3 & 17 & 2 & 2 & 24 & 17 \\
\hline Moderate Vegetation & 0 & 0 & 17 & 1 & 18 & 17 \\
\hline Dense Vegetation & 0 & 0 & 1 & 17 & 18 & 17 \\
\hline Total & 20 & 20 & 20 & 20 & 80 & 68 \\
\hline Overall Accuracy & & & & & $85 \%$ & \\
\hline Kappa (k) Value & & & & & 0.84 & \\
\hline
\end{tabular}

Table 4. The matrix table of NDVI classification after paddy planting period.

\begin{tabular}{|c|c|c|c|c|c|c|}
\hline \multirow[b]{2}{*}{ NDVI Classes } & \multicolumn{4}{|c|}{ Reference Value } & \multirow[b]{2}{*}{ Total } & \multirow[b]{2}{*}{$\begin{array}{l}\text { Correct Sam- } \\
\text { pled }\end{array}$} \\
\hline & $\begin{array}{l}\text { Water } \\
\text { Body or } \\
\text { Bare Area }\end{array}$ & $\begin{array}{l}\text { Sparse Vegeta- } \\
\text { tion }\end{array}$ & $\begin{array}{l}\text { Moderate } \\
\text { Vegetation }\end{array}$ & $\begin{array}{l}\text { Dense Vegeta- } \\
\text { tion }\end{array}$ & & \\
\hline Water Body or Bare Area & 0 & 1 & 5 & 7 & 13 & 0 \\
\hline Sparse Vegetation & 5 & 1 & 6 & 8 & 20 & 1 \\
\hline Moderate Vegetation & 2 & 7 & 6 & 0 & 15 & 6 \\
\hline Dense Vegetation & 13 & 11 & 3 & 5 & 32 & 5 \\
\hline Total & 20 & 20 & 20 & 20 & 80 & 12 \\
\hline Overall Accuracy & & & & & $15 \%$ & \\
\hline Kappa (K) Value & & & & & 0.10 & \\
\hline
\end{tabular}

and 0,84 , respectively. Misclassification rate was obtained from commission error (CE) and omission error (OE) values. CE was defined as number of points that was included in a certain class while they did not belong to the class. Whilst, OE defined as number of points that did not fall in a certain class while they were belong to the class. Sparse vegetation class showed the highest CE $(0,111)$ and OE $(0,15)$, while moderate and dense vegetation classes showed the lowest CE $(0,016)$ and $\mathrm{OE}(0,15)$ (Table 2). The accuracy value normally depended on spectral reflectance of land cover (Kamaruzaman et al., 2009).

User's accuracy value ranged from $71 \%$ to $94 \%$ while producer's accuracy value was $85 \%$. Soft clay area class that classified as water body or bare area was found to be more reliable with $85 \%$ of user's accuracy. With the high accuracy value, it indicated NDVI map in period of before paddy planting was the most suitable period for mapping of soft clay area. In this study, the overall kappa coefficient $(0,84)$ was classified as a good rating criteria of kappa statistic. The mapping of soft clay area was more accurate in period of before paddy planting than the other periods. This was because soft clay area tended to be apparently detected in drying condition. In drying condition, there was not any plant canopy or water that constrained reflectance of soft clay area.

In the study area, soft clay area appeared as bare spots around paddy fields that consisted of patches of water. To 
Table 5. The matrix table of NDVI classification in the harvest period.

\begin{tabular}{|c|c|c|c|c|c|c|}
\hline \multirow[b]{2}{*}{ NDVI Classes } & \multicolumn{4}{|c|}{ Reference Value } & \multirow[b]{2}{*}{ Total } & \multirow[b]{2}{*}{ Correct Sampled } \\
\hline & $\begin{array}{l}\text { Water Body or } \\
\text { Bare Area }\end{array}$ & $\begin{array}{l}\text { Sparse } \\
\text { Vegetation }\end{array}$ & $\begin{array}{l}\text { Moderate } \\
\text { Vegetation }\end{array}$ & $\begin{array}{l}\text { Dense } \\
\text { Vegetation }\end{array}$ & & \\
\hline Water Body or Bare Area & 6 & 0 & 0 & 0 & 6 & 6 \\
\hline Sparse Vegetation & 10 & 11 & 1 & 2 & 24 & 11 \\
\hline Moderate Vegetation & 3 & 7 & 6 & 0 & 16 & 6 \\
\hline Dense Vegetation & 1 & 2 & 13 & 18 & 34 & 18 \\
\hline Total & 20 & 20 & 20 & 20 & 80 & 41 \\
\hline Overall Accuracy & & & & & $51.2 \%$ & \\
\hline Kappa (K) Value & & & & & 0.49 & \\
\hline
\end{tabular}

prove the assumption, we have conducted accuracy analysis using kappa statistic. Result showed $85 \%$ of NDVI value that classified as bare and water body area were accord with ground-truth data. In period of after paddy planting, many soft clay areas were covered by water because paddy fields were drained. Because of this condition, many soft clay areas were not able to be identified by NDVI index. While, in harvest period, paddy fields were completely dried thus many soft clay areas have also been dried that resulted in decreasing of total area of soft clay or NDVI class $(<0,2)$. As a whole, for the best accuracy, the study recommended mapping of soft clay area should be conducted in the first period or before paddy planting.

\section{Conclusion}

Result of study concluded NDVI index had a good potential for mapping of soft clay area in paddy fields. The best estimation of the NDVI index for mapping of soft clay area was showed in period of before paddy planting with overall accuracy $(85 \%)$ and kappa coefficient $(0,84)$. Total area of the soft clay from the highest value was showed in period of before paddy planting $(1.856,97 \mathrm{ha})$ followed by after paddy planting $(656,73 \mathrm{ha})$ and harvest $(401,85 \mathrm{ha})$ periods, respectively. A low total area of soft clay in period of after paddy planting because the paddy fields were drained by irrigation water thus many soft clay areas were covered by water. While, in harvest period, the paddy fields were dried completely thus many soft clay areas were also dried that resulted in decreasing of total area of them. Therefore, based on result of the study, it recommended using the period of before paddy planting for mapping of soft clay area. Soft clay area was detected accurately when the paddy field was in drying condition but it was not too dry.

\section{Acknowledgements}

Authors would like to acknowledge a support from the Economic Transformation Programme Research Fund Scheme (ETP) under a grant number of ETP-2015-003 from Universiti Kebangsaan Malaysia. We also wished to thank
Muda Agricultural Development Authority (MADA) and Green Frontier Technology Sdn. Bhd. helped towards successful and timely implementation of the research project in good time.

\section{References}

Ahmed, M., Else, B., Eklundh, L., Ardo, J., \& Seaquist, J. (2017). Dynamic Response of NDVI to Soil Moisture Variations during Different Hydrological Regimes in the Sahel Region. International Journal of Remote Sensing, 38, 5408-5429.

Ajith, K., Geethalakshmi, V., Ragunath, K. P., Pazhanivelan, S., \& Dheebakaran, G. (2017). Rice yield prediction using MODIS - NDVI (MOD13Q1) and land based observations. International Journal of Current Microbiology and Applied Sciences, 6(12), 2277-2293.

Azizul, G. (2008). Soil hardpan improvement technique using vibrator subsoiler for rice mechanization farm. Bulletin Teknologi Tanaman, 5, 1-4.

Bambang, R., \& Ahmad, B. S. (2017). Identification of paddy field using Landsat image in Karawang Regency, West Java. IOP Conference Series: Earth and Environmental Science, 54(1), 1-8.

Chen, T., De Jeu, R., Liu, Y. Y., Van der Werf, G. R., \& Dolman, A. J. (2014). Using Satellite Based Soil Moisture to Quantify the Water Driven Variability in NDVI: A Case Study over Mainland Australia. Remote Sensing Environment, 140, 330-338.

GopalaPillai, S., \& Tian, L. (1999). In-field variability detection and yield prediction in corn using digital aerial imaging. Transactions of the American Society of Agricultural Engineers, 42, 1911-1920.

Holzman, M. E., Rivas, R., \& Bayala, M. (2014). Subsurface soil moisture estimation by VI-LST method. IEEE Geoscience Remote Sensing Letter, 11, 1951-1955.

Huete, A., Didan, K., Miura, T., Rodriguez, E. P., Gao, X., \& Ferreira, L. G. (2002). Overview of the radiometric and biophysical performance of the MODIS vegetation indices. Remote Sensing Environment, 83(1), 195-213.

Jensen, J. R. (1996). Introductory digital image processing: a remote sensing perspective. New York: Prentice hall, Inc.

Jwan, A. D., Shattri, B. M., \& Helmi, Z. M. S. (2013). NDVI Differencing and Post-classification to Detect Vegetation Changes in Halabja City, Iraq. IOSR Journal of Applied Geology and Geophysics, 1(2), 1-10.

Kamaruzaman, J., Hasmadi, M. I., \& Nurul, H. M. A. (2009). Spectral separability of tropical forest tree species using airborne hyperspectral imager. Journal of Environmental Science and Engineering, 3(1), 37-41.

Mallick, K., Battacharya, B. K., \& Patel, N. K. (2009). Estimating volumetric surface moisture content for cropped soils using 
a soil wetness index based on surface temperature and NDVI. Agricultural Forest Meteorology, 149, 1327-1342.

Mosleh, M. K., \& Hassan, Q. K. (2014). Development of a remote sensing-based "Boro" rice mapping system. Remote Sensing, 6(3), 1938-1953.

Nadzim, M. N., Ayob, A. H., Eddy, H. S., Ahmad, S. S. S., \& Mohamed, F. I. (2014). The replacement soil method for increasing in soil strength at soft soil area. Journal of Technology, 70, 45-47.

New Straits Time. (2013, June 1). Berita Jun 2013. New Straits Time Malaysia. Retrieved from https://www.nst.com.my.

Rendana, M., Idris, W. M. R., Rahim, S. A., Rahman, Z. A., Lihan, T., \& Jamil, H. (2018). Reclamation of acid sulphate soils in paddy cultivation area with organic amendments. AIMS Agriculture and Food, 3, 358-371.

Rendana, M., Idris, W. M. R., Rahim, S. A., Rahman, Z. A., Lihan, T., \& Jamil, H. (2019a). Effects of Organic Amendment on Soil Organic Carbon in Treated Soft Clay in Paddy Cultivation Area. Sains Malaysiana, 48(1), 61-68.

Rendana, M., Idris, W. M. R., Rahim, S. A., Rahman, Z. A., Lihan, T., \& Jamil, H. (2019b). Field investigation of soil organic carbon and soil respiration rate from paddy cultivation area of Alor Senibong Kedah, Malaysia. AIP Conference Proceedings, 2111(1), 1-7.

Rendana, M., Rahim, S. A., Idris, W. M. R., Lihan, T., \& Rahman, Z. A. (2016). Mapping nutrient status in oil palm plantation using geographic information system. Asian Journal of Agricultural Research, 10(3), 144-153.

Rendana, M., Rahim, S. A., Idris, W. M. R., Lihan, T., \& Rahman, Z. A. (2017). Soil erosion assessment in Tasik Chini catch- ment using remote sensing and GIS techniques. Sains $M a$ laysiana, 46(4), 529-535.

Rouse, J. W., Haas, R. H., Schell, J. A., \& Deering, D. W. (1974). Monitoring vegetation systems in the great plains with erts. Proceedings of Third ERTS Symposium, 1, 309-317.

Shafian, S., \& Maas, S. J. (2015) Index of soil moisture using raw Landsat image digital count data in Texas High Plains. Remote Sensing, 7, 2352-2372.

Wang, X., Hongjie, X., Guan, H., \& Zhou, X. (2007). Different Responses of MODIS-Derived NDVI to Root-Zone Soil Moisture in Semi-Arid and Humid Regions. Journal of Hydrolo$g y, 340,12-24$. 